KS. MARCIN BIDER

Wydział Nauk Społecznych

Uniwersytetu Przyrodniczo-Humanistycznego w Siedlcach ORCID: 0000-0001-9446-1753

\title{
FORMY KANONICZNEJ ZALEŻNOŚCI INDYWIDUALNEGO EREMITY OD HIERARCHII KOŚCIELNEJ W POTRYDENCKICH ŹRÓDŁACH PRAWA KOŚCIOŁA ŁACIŃSKIEGO
}

Treść: Wstęp. - 1. Sobór Trydencki (1545-1563). - 2. Prawodawstwo papieskie. - 3. Ustawodawstwo synodalne. - 4. Dekrety ordynariuszy miejsca. - 5. Poglądy kanonistów. - Podsumowanie.

\section{Wstęp}

W celu przedstawienia określonej metodologicznie wizji anachorety, czyli pustelnika, zależnego od biskupa diecezjalnego w zakresie źródeł prawa kanonicznego, zostaną poddane analizie m.in. następujące źródła: 1) prawodawstwo kościelne: kanony soborów powszechnych, ustawy synodów prowincjalnych i diecezjalnych, dekrety biskupów diecezjalnych; 2) normy ustawodawstwa prawa świeckiego; 3) reguły i ustawy partykularne regulujące status eremity na poziomie diecezji lub lokalnej wspólnoty świeckiej; 4) normy indywidualnie określające status prawny eremity; 5) protokoły powizytacyjne, wizyty „ad limina Apostolorum” oraz zapisy księgi „De statu animarum"; 6) spisy pustelników z uwzględnieniem ich imion, nazwisk, kraju pochodzenia, poprzednich miejsc przebywania wraz z danymi o obłóczynach; 7) zapisy prowadzone przez trzecie zakony, do których mieli zostać agregowani pustelnicy; 8) jurysprudencja 
traktująca instytucję anachorety pod względem prawnym i moralnym „De foro competenti”; 9) literatura z zakresu ascetyki; 10) dokumenty odnoszące się do poszczególnych eremitów. Powyższy wykaz źródeł został zaproponowany przez F. Ferrero w odniesieniu do badań prowadzonych nad anachoretyzmem, rozwijającym się od XV wieku1.

\section{Sobór Trydencki (1545-1563)}

Sobór Trydencki „explicite” nie podjął zagadnień związanych $\mathrm{z}$ anachoretyzmem ${ }^{2}$, ponieważ zgromadzenie ojców soborowych zwołane w celu przeprowadzenia reformy katolickiej w obliczu zarzutów formułowanych przez teologów protestanckich, koncentrowało się na zagadnieniach przede wszystkim doktrynalnych. Jednakże ojcowie soborowi podczas V sesji 17 czerwca 1546 r. $^{3}$ zajęli się uregulowaniem prawnej sytuacji kwestarzy ${ }^{4}$. Sobór Trydencki zakazał poborcom jałmużny, potocznie zwanym kwestarzami, wygłaszania kazań;

\footnotetext{
${ }^{1}$ F. Ferrero, Eremitismo individuale in Occidente (dal sec. XV), w: Dizionario degli Istituti di Perfezione, t. III, red. G. Pelliccia, G. Rocca, Roma: Edizioni Paoline, 1976, kol. 1246.

${ }^{2}$ Chociaż Sobór Trydencki nie zanegował samej wartości anachoretyzmu, to jednak niewątpliwie zauważył konflikt zachodzący pomiędzy koniecznością zaspokajania potrzeb materialnych przez anachoretę a obowiązkiem przestrzegania przez niego samotności. Problem rysującej się sprzeczności należałoby postrzegać w kontekście „devotio moderna” (pop. U. Borkowska, M. DANiluk, Devotio moderna, w: Encyklopedia katolicka, t. III, red. R. Łukaszyk i [in.], Lublin: TN KUL 1989, kol. 1220-1222; pop. [b.a.], De imitatione Christi libri quatuor, lib. I, cap. 20, red. T. Lupo, Città del Vaticano: Libreria Editrice Vaticana, 1982, s. 57-62).

3 „Quaestores vero eleemosynarii, qui etiam quaestuarii vulgo dicuntur, cuiuscumque conditionis existant, nullo modo, nec per se, nec per alium praedicare praesumant: et contrafacientes ab episcopis, et ordinariis locorum, privilegiis quibuscumque mon obstantibus, opportunis remediis omnimo arceantur" (Concilium Tridentinum, sessio V, 17 iunii 1546, [sub Paulo III], II. Decretum secundum: super lectione et praedictione, nr 17, w: Dokumenty soborów powszechnych. Tekst łaciński, polski, t. IV, [1511-1870]. Lateran V. Trydent, Watykan I, red. A. Baron, H. Pietras, Kraków: Wydawnictwo WAM, Księża Jezuici, 2005, s. 248, w. 26-30).

${ }^{4}$ M. DAniluk, Kwesta, w: Encyklopedia katolicka, t. X, red. E. Ziemann i [in.], Lublina: TN KUL 2004, kol. 294-295.
} 
wykonawcami tej decyzji zostali rezydencjalni biskupi oraz ordynariusze miejsca. Ojcowie soborowi podczas sesji 16 lipca 1562 r. zajęli się również samym zjawiskiem zbierania jałmużny ${ }^{5}$. Sobór ze względu na potwierdzone nadużycia, zgorszenia i nieużyteczność, postanowił znieść instytucję poborców jałmużny. Postanowiono równocześnie, aby odpusty lub inne duchowe łaski miały być odtąd ogłaszane przez ordynariuszy miejsca przy udziale dwóch przedstawicieli kapituły. Biskupom przy tej okazji przyznano prawo zbierania jałmużny oraz innych darów. Należy nadmienić, że eremici zazwyczaj utrzymywali się z jałmużny, a w przypadku braku posiadania przez nich stałych dochodów, stawało się to wręcz koniecznością ${ }^{6}$.

Anachoretyzm w kontekście nowych warunków społeczno-ekonomicznych rozwijających się w XVI w. do pewnego stopnia został utożsamiony ze społecznym zjawiskiem włóczęgostwa7 ${ }^{7}$

${ }^{5}$ „[...] Statuit ut posthac in quibuscumque christianae religionis locis eorum nomen atque usus penitus aboleatur nec ad officium huiusmodi exercendum ullatenus admittantur non obstantibus privilegiis ecclesiis monasteriis hospitalibus piis locis et quibusvis cuiuscumque gradus status et dignitatis personis concessis aut consuetudinibus etiam immemorabilibus" (Concilium Tridentinum, sessio XXI, 16 iulii 1562, [sub Pio V], II. Decretum de reformatione, can. 9, w: Dokumenty soborów powszechnych. Tekst łaciński, polski, t. IV [1511-1870]. Lateran V. Trydent, Watykan I, red. A. Baron, H. Pietras, Kraków: Wydawnictwo WAM, Księża Jezuici, 2005, s. 624, w. 10-15).

${ }^{6}$ Chociaż Sobór Trydencki podjął próbę skasowania kwesty to jednak pap. Pius $\mathrm{V}$, nie chcąc pogarszać sytuacji materialnej zakonników, bullą Etsi mendicantium z 16 czerwca 1567 r. potwierdził prawo zakonów żebrzących do zbierania jałmużny, a także nadał prawo do kwesty jezuickim domom bez stałych dochodów, które zamieszkiwane byłyby przez profesów z czterema ślubami (S. PIUs V, Constitutio Etsi mendicantium, 16 iunii 1567, w: Codicis Iuris Canonici Fontes, t. I, red. P. Gasparri, Romae: Typis Polyglottis Vaticanis, 1926, s. 217-220, nr 121; M. Daniluk, Kwesta, kol. 295; Pius PAPA V, Dum indefessae, 7 iulii 1571, w: Institutum Societatis Iesu, t. I, Bullarium et compendium privilegiorum, Florentiae: Typographia a SS. Conceptione, 1892, s. 46-49).

${ }^{7}$ W 1545 r. w Królestwach Francji i Anglii wprowadzono podatek przeznaczony na pomoc dla ubogich. Na przykład w XVII w. w Paryżu, liczącym wówczas około 200 tys. mieszkańców, doliczono się aż około 40 tys. żebraków. W tej sytuacji w 1662 r. król Ludwik XIV († 1715) wydał edykt nakazujący miastom Królestwa 


\section{Prawodawstwo papieskie}

Pap. Pius V († 1572) w konstytucji apostolskiej „Circa pastoralis” z 1566 r. ${ }^{8}$ zredukował znaczenie życia zakonnego zasadniczo do instytutów zakonnych o ślubach uroczystych. Wszystkie pozostałe instytuty, w tym także stowarzyszenia, naśladujące w różnym stopniu ideał życia zakonnego, w tym również o charakterze eremickim, nie uzyskały statusu zakonów. Papież uznał złożenie uroczystej profesji jako istotny element życia zakonnego ${ }^{9}$. Stolica Apostolska w okresie potrydenckim nie uznawała instytutów za zakony, w których członkowie składaliby tylko jedynie śluby proste ${ }^{10}$. Rezydencjalni biskupi, systematycznie z całą konsekwencją, dostrzegając nowe potrzeby Kościoła katolickiego i ówczesnego społeczeństwa, podejmowali próby zmierzające do erygowania nowych lub zatwierdzenia już istniejących instytutów o ślubach prostych, albo przynajmniej do kanonicznego aprobowania ich konstytucji ${ }^{11}$. Stolica Święta w okresie potrydenckim, wykluczając kanoniczne zatwierdzenie instytutów o ślubach prostych jako zakonów, zamieszczała jedynie klauzulę (tzw. „salutaris"), na podstawie której instytuty bez składania uroczystej profesji i zachowania papieskiej klauzury były jedynie tolerowane ${ }^{12}$. Dopiero od połowy XIX w. swego rodzaju stanowczość Stolicy Świętej wobec nieuznawania instytutów o ślubach prostych za zakony zaczęła ulegać pewnemu osłabieniu ${ }^{13}$.

Francji zorganizowanie szpitali dla ubogich („hospital general”), przeznaczonych dla kilku tysięcy osób dorosłych oraz dzieci. Koszty utrzymania tych szpitali miały obowiązek pokrywać miejskie władze; „reguła życia” w tych szpitalach upodobniała je do klasztorów (T. WróBlewsKa, Problem opieki nad dzieckiem. Rys historyczny, Mazowieckie Studia Humanistyczne 1 [1998], s. 36).

${ }^{8}$ S. Pius V, Constitutio Circa pastoralis, 29 maii 1566, w: Codicis Iuris Canonici Fontes, t. I, red. P. Gasparri, Romae: Typis Polyglottis Vaticanis, 1926, s. 201-203, nr 112.

${ }^{9}$ J. KAŁOWsKi, Ewolucja prawodawstwa kościelnego dotyczącego instytutów zakonnych o ślubach prostych, Prawo Kanoniczne 34 (1991), nr 3-4, s. 78.

${ }^{10}$ Tamże, s. 80.

${ }^{11}$ Tamże, s. 85.

12 Tamże, s. 86.

13 Tamże, s. 67. 
Pap. Pius X († 1914), pragnąc uregulować kwestię uznania „zakonności” instytutów o ślubach prostych, wydał 16 lipca 1906 r. motu proprio „Dei providentis”" . Według promulgowanych norm żaden rezydencjalny biskup ani jakikolwiek inny ordynariusz miejsca nie mógł odtąd erygować nowego instytutu ani udzielać zgody na jego erekcję bez uprzednio uzyskanego pisemnego pozwolenia Stolicy Apostolskiej. W celu otrzymania pozwolenia ordynariusz miejsca zobowiązany był do zwrócenia się z pisemną prośbą do Kongregacji Biskupów i Zakonników przekazując jej informacje: o założycielu instytutu; nazwie; formie prawnej; materiale (kolorze), z którego miał zostać wykonany zakonny habit. Postanowiono ponadto, że należało przesłać informację o celu instytutu, środkach utrzymania oraz czy istniały już w danej diecezji podobne instytuty. Ordynariusz miejsca dopiero po otrzymaniu pozwolenia wydanego przez Stolicę Apostolską mógł erygować lub pozwolić na erekcję instytutu, ale nie mógł zmienić bez zgody Stolicy Apostolskiej nazwy, celu oraz charakteru instytutu. Ponadto do ordynariusza miejsca należało zatwierdzenie konstytucji erygowanego instytutu; konstytucje te należało sporządzić zgodnie z wytycznymi Kongregacji Biskupów i Zakonników ${ }^{15}$.

\section{Ustawodawstwo synodalne}

Wraz z ekspansją reformy katolickiej zanotowano w krajach o przewadze ludności katolickiej wzrost znaczenia indywidualnej formy życia eremickiego. Szczególny swego rodzaju rozkwit życia anachoreckiego zaobserwowano m.in. na ziemiach germańskich rządzonych przez arcyksiążąt $z$ dynastii Habsburgów i Witttelsbachów. Znaczący rozwój form życia indywidualnego i niezależnego anachoretyzmu zaobserwowano również w krajach romańskich: a więc na ziemiach monarchii hiszpańskiej, na terytoriach należących do państw położonych na Półwyspie Apenińskim, a po 1590 r., zwłaszcza

\footnotetext{
${ }^{14}$ Pius PP. X, Motu proprio Dei providentis, w: Pii X Pontificis Maximi Acta, t. III, Romae: Ex Typographia Polyglotta Vaticana, 1908, s. 141-143.

${ }^{15}$ KaŁowski, Ewolucja, s. 94-95.
} 
za rządów króla Ludwika XIII (†1643), również w Królestwie Francji. Równocześnie wraz ze wzrostem znaczenia anachoretyzmu w katolickich krajach, nasilała się również i jego krytyka. Przeciwko zjawisku anachoretyzmu podnoszono wiele zastrzeżeń, wśród których często pojawiał się zarzut nadmiernego hołdowania przez eremitów ubóstwu i włóczęgostwu. Sytuację, również pod względem kanonicznym, zaogniały konflikty rodzące się pomiędzy stanem duchownym (szczególnie duchowieństwa diecezjalnego) a anachoretami; dezawuowano m.in. eremickie formy działalności duszpasterskiej oraz przejawy pobożności. Poszczególni ordynariusze miejsca, pragnąc poddać jak dotąd niezależnych eremitów swej władzy, przeciwdziałając równocześnie dyscyplinarnym nadużyciom, począwszy od początku XVII w., promulgowali na lokalnych synodach normy, które miały na celu uporządkowanie życia anachoretów ${ }^{16}$.

W okresie potrydenckim promulgowano statuty dla eremitów m.in. na następujących synodach ${ }^{17}$ : Vigo (1591), Cambrai $(1631)^{18}$, S.-Omer (1640), Besançon $(1605)^{19},(1656)^{20}$, Bordeaux $(1624)^{21}$, Grasse

${ }^{16}$ M. DAniluk, Eremici. III. W Kościele zachodnim, w: Encyklopedia katolicka, t. IV, red. R. Łukaszyk i [in.], Lublin: TN KUL, 1989, kol. 1076.

${ }^{17}$ Pop. J. Pérez de Urbel, Eremitismo, w: Diccionario de historia ecclesiastica de España, t. II, red. Q. Aldea Vaquero I i [in.], Madrid: Instituto Enrique Florez, 1972, s. 801-804; pop. Ph. Roulllard, Eremitismo. II. In Occidente, w: Dizionario degli istituti di perfezione, t. III, red. G. Pelliccia, G. Rocca, Roma: Edizioni Paoline, 1976, kol. 1230-1236).

${ }^{18}$ Concilium Cameracen. (1631), Decreta et statuta, tit. XXII. De regularibus et monialibus, 24, w: Sacrorum Conciliorum Recentiorum Ecclesiae Universale. Synodi occidentales, 1610-1719, red. L. Petit, I.B. Martin, Arhem, Leipzig: H. Welter, 1924, kol. 191.

${ }^{19}$ Concilium Bisutin. (1605), w: Collectio Conciliorum Recentiorum Ecclesiae Universale. Synodi occidentales, 1569-1609, red. L. Petit, I.B. Martin, Parisiis: Huberti Welter, 1913, kol. 959.

${ }^{20}$ Concilium Bisutin. (1656), w: Sacrorum Conciliorum, 1610-1719, kol. 347.

${ }^{21}$ „Regulares quicunque, sine licentia suorum superiorum vagantes, ab Episcopis locorum puniantur, et ad ipsos superiores, ut institutum suum servent, remittantur. Eremitæ vero sine licentia Episcoporum episcopis subjecti, sine eorumdem episcoporum licentia, à cellulis discedere non præsumant, aut secus severe coërceantur" (Concilium Burdigalen. [1624], Decreta Concilii Provincialis Burdegale ab 
i Vence (1666), Reims (1672), Albano (1687) ${ }^{22}$, Grenoble (1690) ${ }^{23}$, Bruges $(1693)^{24}$, Namur (1698), Die (1698) ${ }^{25}$, Marsylia (1712), Rzym (1725) ${ }^{26}$, Cariati (1726), Dijon (1743), Carpentras (1756).

\section{Dekrety ordynariuszy miejsca}

Pod koniec XVI w. zaczęto erygować kongregacje eremitów jednak bez statusu zakonów. A. Rossieli Cedraro ufundował np. w Rzymie w 1588 r. kongregację „Eremiti dell'Ascensione di Nostro Signore e della Beatissima Vergine delle Grazie a Porta Angelica" przy kościele „Madonna delle Grazie” obok Porta Angelica, której członkowie nie składali ślubów. Eremici otaczali opieką eremitów pielgrzymów,

Eminentissis et Reverendissimis Cardinalibus correcta, cap. XVII, De Monasteriis 3 , w: Archives historiques du département de la Gironde, t. XVII, red. M. Jules Delpit, Bordeaux: Charles Lefebvre 1877, s. 460; dostęp: http://gallica.bnf.fr/ark:/12148/ bpt6k341166/f496.item [31.10.2018]).

${ }^{22}$ „Ad perditorum, et diuagantium quorumdam hominum, eludendam fraudem, atque malitiam, qui sub ementito quandoque Eremitarum habitu" (Synodus dioecesana Albanensis ab Eminentis. ac Reverendis. D.D. Flavio S.R.E Card. Chisio Episcopo Albanensis Celebrata in Ecclesia Cathedrali sub diebus XXV. XXVI. et XXVII. mensis maii Anno à reparata salute MDCLXXXVII, $\$ \$ 8-10$, Romae: Typis Io. Iacobi Komarek Bohemi, 1689, s. 109-110); dostęp: https://play.google.com/books/ reader?id=c3eapdcx5MEC \&printsec=frontcover\&output=reader\&hl=pl\&pg=GBS. PP7

${ }^{23}$ Concilium Gratianopolitan. (1690), Ordonnances synodales $d u$ diocèse de Grenoble, lib. III, art. 1, Ordre de la visite, 13, Grenoble: Giroud 1691, s. 131 (dostęp: https://books.google.pl/books?redir_esc=y\&hl=pl\&id=B9t7EGhggXoC\&q=ermit $\# \mathrm{v}=$ onepage\&q=eremita\&f=false, [31.10.2018]).

${ }^{24}$ Concilium Brugen. (1693), w: Sacrorum Conciliorum, 1610-1719, kol. 651.

${ }^{25}$ Concilium Dien. (1698), Ordonnances synodales du diocese de Die, 23, Grenoble: A. Giroud, 1698, s. 113-123; dostęp: https://books.google.pl/books?id=l-4c2hIzg58C \&printsec $=$ frontcover\&hl=pl\&source $=$ gbs_ge_summary_r\&cad $=0 \# v=$ onepage \&q $\& \mathrm{f}=$ false $(31.01 .2018)$.

${ }^{26}$ Concilium Romanum in Sacrosancta Basilica Lateranensi Celebratum Anno Universalis Jubilaei MDCCXXV 1725. a Sanctissimo Patre et Domino Nostro Benedicto Papa XIII. Pontificatus Sui Anno I., tit. XXII, De statu Monachorum et Eremitarum, Romae: Ex Typographia Rocchi Bernabò, 1725, s. 89-90; dostęp: https://play.google. com/books/reader?id=epReQxOChaAC\&printsec $=$ frontcover\&output=reader\&hl $=$ pl\&pg=GBS.PP5 (21.01.2018). 
których zobowiązano w 1606 r. do korzystania z hospicjum prowadzonego przez tę kongregację. Swoją działalność kongregacja finansowała ze środków pochodzących z jałmużny. Kongregacja eremitów w XIX w. przeżywała kryzys i dlatego protektor kongregacji I.D. Caracciolo w 1806 r. skasował ją z powodu zbyt małej liczby członków ${ }^{27}$.

Oryginalnym wkładem XVII-wiecznej myśli francuskiej było erygowanie w Królestwie Francji instytutów eremickich o charakterze niezakonnym. Pod koniec panowania króla Ludwika XIV (†1715) istniało w Królestwie Francji dziesięć kongregacji eremickich. Grupy eremickie erygowane w Królestwie Francji i krajach Rzeszy Niemieckiej w XVII-XVIII w. nie różniły się zasadniczo dyscypliną od małych wspólnot typu kamedulskiego ${ }^{28}$.

Charles Pérusse des Cars ( $† 1614)$, biskup Langres, około $1604 \mathrm{r}$. zgromadził eremitów rozproszonych podczas szesnastowiecznych wojen, lecz jego dzieło zostało ukończone dopiero w 1623 r. przez jego następcę biskupa Sébastien’a Zamet’a ( $† 1655)$. Opublikował on, z inspiracji o. Michała od św. Sabiny (†1650) w 1623 r. w Langres Letteres aux ermites du diocèse de Langres sous l'invocation de St-Jean Baptiste $\mathrm{z}$ załączonym regulaminem życia eremitów ${ }^{29}$. Eremitów podzielił na trzy dystrykty: Chaumontois, Langrois i Tonnerrois. Na czele każdego dystryktu stanął wizytator, który podlegał wizytatorowi generalnemu. Eremy były wizytowane przez wizytatora generalnego pod nadzorem wikariusza generalnego w trzecim tygodniu po Wielkanocy. W 1684 r. wizytatorem generalnym eremitów w diecezji Langres został mianowany Jérôme de Saint Joseph (Jacques Chevreteau [†1711]). Eremici mieli obowiązek przebywania po dwóch w każdym eremie, noszenia białego habitu przepasanego skórzanym paskiem, chodzenia na boso w lecie, a w zimie noszenie obuwia. Eremitów, cieszących się umiejętnością czytania, zobowiązano do recytacji Officium Parvum Beatae Mariae Virginis oraz psalmów pokutnych wraz z litanią do

\footnotetext{
${ }^{27}$ M. Daniluk, J. Duchniewski, Eremici. IV. Wspólnoty, w: Encyklopedia katolicka, t. IV, red. R. Łukaszyk i [in.], Lublin: TN KUL, 1989, kol. 1081.

${ }^{28}$ DANILUK, Eremici, kol. 1077.

${ }^{29}$ Kolejne wydania: 1680, 1697 i 1725; DAniluk, Eremici, kol. 1077.
} 
wszystkich świętych we wszystkie piątki w ciągu roku. Pozostali eremici „illiterati” mieli obowiązek odmawiania dwóch różańców oraz 33 „Ojcze Nasz” i „Zdrowaś Maryja”. Eremici utrzymywali się z pracy rąk własnych; w niedziele i nakazane święta mieli obowiązek gromadzenia się w parafialnych świątyniach. Zdarzało się, że eremici w diecezji Langres nie akceptowali przysyłanych im z zewnątrz wizytatorów, ponieważ miejscowi proboszczowie, uważając się za właścicieli eremitarzy, podsycali w eremitach nieufność wobec przybyszów. W przypadku braku eremitów ich eremitarze zasiedlały osoby świeckie, które opiekowały się kaplicami, uprawiały warzywne ogrody i zajmowały się konserwacją zabudowań. Nie należało również do rzadkości, że stróże eremów rekrutowali się z okolicznej ludności odznaczającej się niskim poziomem wykształcenia; wiązało się to czasami również z nagannym stylem życia nowych mieszkańców eremów. Ponieważ drastycznie spadała liczba eremitów, dlatego César-Guillaume de La Luzerne (†1802), biskup Langres, podjął decyzję o wprowadzeniu zakazu zastępowania eremitów przez osoby świeckie. Następnie eremy podczas rewolucji francuskiej zniesiono, a ich dobra znacjonalizowano ${ }^{30}$.

Kardynał J.F. de Gondi, arcybiskup paryski (†1654), 19 lutego 1627 r. zakazał eremitom z lasów Sénart („Ermitage de Notre-Dame-de-Consolation") przebywania na terenie swej archidiecezji z powodu prowadzenia niezbyt budującego stylu życia. Następnie jeden z kamedułów za pozwoleniem przełożonych własnej kongregacji przybył do eremu w lesie Sénart w 1667 r. i wraz z kilkoma towarzyszami bezskutecznie próbował wskrzesić prowadzenie regularnego życia eremickiego. Przeorat (a właściwie erem w lesie Sénart) od 1690 r. kanonicznie podlegał opactwu kanoników regularnych w Hiverneau oraz kamedułom z Abbaye Notre-Dame d'Yerres. Pachomiusz opublikował w 1703 r. rozprawę Mémoire de l'établissement de la chapelle et ermitage de N.D. de Consolation en la Forêt de Sénart, w której m.in. zamieścił regułę

${ }^{30}$ P. Cousin, Eremiti di San Giovanni Battista, in Francia, w: Dizionario degli Istituti di Perfezione, t. III, red. G. Pelliccia, G. Rocca, Roma: Edizioni Paoline, 1976, kol. 1209-1210. 
dla eremitów. Wyniki badań wskazują, że wspomniani pustelnicy prowadzili życie bardziej cenobityczne niż eremickie. Chociaż erem podlegał jurysdykcji przełożonego, którego mianował arcybiskup paryski, zarząd sprawami codziennymi spoczywał na barkach jednego z członków wspólnoty eremitów, który był wybierany na okres trzech lat. Eremici spośród siebie wybierali również asystenta, do zadań którego należało troszczenie się o stan materialny i duchowy eremu, mistrza nowicjatu, ekonoma oraz prefekta, którego zadaniem było troszczenie się o dobrą organizację pracy. Pustelnicy utrzymywali się z pracy ręcznej, wytwarzając cenioną przez paryżanki tkaninę zw. „sénardine”. Nowicjusze mogli składać profesję dopiero po ukończeniu 21. roku życia. Zabroniono eremitom przyjmowania święceń prezbiteratu oraz przyjmowania prezbiterów do wspólnoty. Biskup Anne-Charles-Frédéric de la Trémoille 22 maja 1739 r. położył kamień węgielny pod przebudowywany kościół Notre-Dame-de-Consolation, który dedykowano 3 listopada 1751 r.; eremitów w 1794 r. zmuszono do opuszczenia eremu ${ }^{31}$.

Biskup Toul w 1708 r. erygował Kongregację Eremitów św. Jana Chrzciciela, którą następnie w 1772 r. przyłączono do Kongregacji Eremitów św. Antoniego obecnej kanonicznie w diecezji Toul już od 1676 r. Nowa kongregacja eremitów swoim zasięgiem obejmowała terytorium diecezji: Toul, Nancy i Saint-Dié. Kongregacja pod

\footnotetext{
${ }^{31}$ Lasy Sénart są położone około $20 \mathrm{~km}$. na południowy wschód od Paryża w pobliżu miasta Corbei. Przeorat (erem) ufundował król Ludwika IX ( $\uparrow 1270)$, który w lasach Sénart urządzał polowania; przeorat-erem przejściowo opuszczono w XVI w., aby go później na nowo zasiedlić; jednym z eremitów był m.in. książe d’Arces, który zamieszał w lasach Sénart w 1558 r., wielokrotnie odwiedzany przez króla Henryka IV (Daniluk, Duchniewski, Eremici. IV. Wspólnoty, kol. 1081; Honoré FISQUET, La France pontificale [Gallia christiana]. Histoire chronologique et biographique des archevêques et évêques de tous les diocèses de France depuis l'établissement du christianisme jusqu'à nos jours, divisée en 17 provinces ecclésiastique, t. I, Paris: E. Repos, 1864, s. 393-394; B.D.E., SÉnA RT [Ermies de la Forét de], Dictionnaire des ordres religieux, ou histoire des ordres monastiques, religieux et militaires, t. IV, red. H. Helyot, Paris: J.-P. Migne, 1859 kol. 1395-1402; PH. RouILlard, Eremiti della Foresta di Sénart, w: Dizionario degli Istituti di Perfezione, t. III, red. G. Pelliccia, G. Rocca, Roma: Edizioni Paoline, 1976, kol. 1159).
} 
względem statystycznym w 1790 r. liczyła 25 eremów z 65 eremitami ${ }^{32}$. François Blouet de Camilly (†1723), biskup Toul, 30 września $1711 \mathrm{r}$. w Ordonnance de M. l'Evêque-comte de Toul touchant la clôture des monastères religieus ${ }^{33}$ przypominał eremitom o obowiązku zachowywania klauzury i przestrzegania norm kanonicznych ${ }^{34}$. Ten sam biskup Toul 27 czerwca 1712 r. zalecił eremitom lekturę dzieła $\mathrm{La}$ Doctrine amoureuse ou le catéchisme d'amour, où sont enseignez les principaux mystères de l'amour et le devoir d'un véritable amant ${ }^{35}$. Sytuację prawną eremitów diecezji Toul normowały również zarządzenia Léopold’a I duc de Lorraine $(\dagger 1729)^{36}$.

Ferdynand Khuenburg (†1731), arcybiskup praski, podjął inicjatywę nadania eremitom, pozostającym w granicach jego jurysdykcji, formy życia w postaci instytutu. Arcybiskup, po uzyskaniu uprzedniej zgody od pap. Klemensa XII (†1740) i ces. Karola VI Habsburga ( $\dagger 1740)$, powierzył przeprowadzenie tej reformy nauczycielowi z Jablonne w Królestwie Czech, Dominikowi Antoniemu Stey’owi, który zredagował dla nich regułę zatwierdzoną następnie

${ }^{32}$ Ph. Roulllard, Eremiti di San Giovanni Battista, III, w: Dizionario degli Istituti di Perfezione, t. III, red. G. Pelliccia, G. Rocca, Roma: Edizioni Paoline, 1976, kol. 1210 .

${ }^{33}$ E. Martin, Histoire des diocèses de Toul, de Nancy et de Saint-Dié, t. II, Nancy: A. Crépin-Leblond, 1901, s. 421, przyp. 2.

${ }^{34}$ F. Blouet de Camilly, Ordonnance de M. l'Evêque de Toul, sur les obligations de la vie èrèmitique, adress aux Freres de la Cogregations de Saint-Antione, 3 września 1708 r., w: Martin, Histoire des diocèses, s. 421, przyp. 2; F. BLOuET DE CAmilly, Qui ordonne l'Execution d'un Decret de M. l'Evêque de Toul, touchant les Gardes-Chapelles Champêtres, du 4 Avril 1716, w: Recueil des édits, ordonnances, declarations, traitez et concordats du regne de Leopold I., t. II, Nancy: Cusson, 1733, s. 93-95.

${ }^{35}$ Martin, Histoire des diocèses, s. 421, przyp. 2.

${ }^{36}$ LeOpold I, Portant Réglement pour les Hermites résidans en Lorraine, 9 lipca 1701, w: Recueil des édits, ordonnances, declarations, traitez et concordats du regne de Leopold I., t. I, Nancy: Cusson, 1733, s. 294-295; Tenże, Qui régle que les Hermites, quoique véritablement Laiques, 4 lipca 1701, w: Recueil des édits, t. I, s. 364-367; Tenże, Qui défend aux Hermites, 15 stycznia 1703, w: Recueil des édits, t. I, s. 376378; Tenże, Portant union des Chapitres de Hattonhcatel, 20 lipca 1707, w: Recueil des édits, t. I, s. 600-615. 
28 kwietnia 1732 r. Powołano do życia kongregację eremitów, których zobowiązano do przyjęcia za patrona któregoś z ojców Kościoła oraz do noszenia habitu z różańcem i krzyżem. Każdy członek kongregacji został zobowiązany do przebywania na stałe w wybranym przez siebie eremie. Stałym wizytatorem kongregacji miał być mianowany za każdym razem jeden z kanoników praskiej kapituły archikatedralnej. Ponadto wydano dekret, publikowany jeszcze kilkakrotnie, na mocy którego wszyscy eremici pozostający na terenie Królestwa Czech stawali się członkami tej kongregacji, której pełna nazwa brzmiała „Congregatio fratrum eremitarum divi Ivani” lub „Congregatio fratrum a sancta Maria" ${ }^{37}$. Kongregacja szybko wzrastała w liczbę i stała się przedmiotem podziwu ze strony prostego ludu, ceniącego sobie obecność eremitów, których liczba sukcesywnie wzrastała w Królestwie Czech. W praskim kościele św. Jana „u Slepé brány” otwarto hospicjum dla członków tej kongregacji. Równocześnie jednak wielu eremitów odrzuciło przynależność do kongregacji, co spowodowało, że ich liczba w 1768 r. wynosiła zaledwie 32 członków. Władze administracyjne w $1771 \mathrm{r}$. rozpoczęły śledztwo w sprawie domniemanych bogactw zgromadzonych przez eremitów, co doprowadziło w końcu do tego, że cesarz Józef II (†1790), realizując wyznaniową politykę, zw. „józefinizmem”, 12 stycznia 1782 r. zniósł kongregację liczącą 17 członków ${ }^{38}$.

Rezydencjalni biskupi rezerwowali sobie np. prawo dopuszczania kandydatów do życia eremickiego, nakładania habitu, mianowania jednego z kapłanów na urząd mistrza nowicjatu, zmiany rezydencji

\footnotetext{
${ }^{37}$ Bł. Ivan, czeski eremita, którego działalność datuje się na X w.; wiadomości o jego życiu pochodzi z dzieła „Vita” powstałego w języku starosłowiańskim w XIV-XV w. (Bibliotheca hagiographica latina antiquae et mediae aetatis, t. I, red. Société des Bollandistes, Bruxelles: Société des Bollandistes, 1898, s. 684, nr 4618). Jego kult swymi początkami sięga XV w., chociaż kaplicę jemu dedykowaną zw. „Svatý Jan pod Skalou” erygowano już w 1205 r., gdzie prascy benedyktyni podczas wojen husyckich znaleźli schronienie (T. ŠpıdLík, Eremiti, di Boemia o Ivaniti, w: Dizionario degli Istituti di Perfezione, t. III, red. G. Pelliccia, G. Rocca, Roma: Edizioni Paoline, 1976, kol. 1157).

38 Tamże, kol. 1157-1158.
} 
oraz dopuszczania do profesji. Ponadto rezydencjalni biskupi rezerwowali sobie prawo do mianowania diecezjalnych dyrektorów do spraw eremitów z władzą wikariuszy generalnych, którzy zazwyczaj pochodzili z jednego ze „starych zakonów”. W celu przeciwdziałania nadużyciom piętnowano na synodach zjawisko „fałszywych eremitów”, którzy oddawali się próżniaczemu trybowi życia. Arcybiskup Jean-Pierre Camus ( $\uparrow 1562)$, francuski poczytny pisarz, w Hermiante ou les deux Hermites contraires (Rouen: J. de La Mare, 1639) ${ }^{39}$ piętnował oszustów, podających się za eremitów, których niektórzy francuscy biskupi usuwali ze swych diecezji. Niektórzy francuscy biskupi porządkowali pod względem kanonicznym eremickie życie. Przykładem może posłużyć np. promulgowanie w 1714 r. przez arcybiskupa François’a de Salignac de la Mothe-Fénelon $(\dagger 1715)^{40}$ norm dla eremitów zamieszkujących diecezję Cambrai. Arcybiskupa Fénelon, realizując postanowienia rzymskiego synodu z 1725 r. $^{41}$, erygował według "francuskiego modelu” zgromadzenie eremitów diecezji Cambrai ${ }^{42}$.

Charles-Auguste de Sales († 1660) zrzekł się w 1635 r. urzędu przełożonego genewskiej katedralnej kapituły, generalnego wikariusza genewskiej diecezji oraz proboszcza parafii „Nostra Signora

\footnotetext{
${ }^{39}$ Daniluk, Eremici, kol. 1076-1077. Biskup Jean-Pierre Camus († 1652), teolog, kaznodzieja i pisarz, w 1609 r. przyjął sakrę biskupią i objął rządy w Belley, jednakże popadł w ostry konflikt z zakonami żebrzącymi, co stało się przyczyną jego rezygnacji z urzędu biskupiego. Osobiste doświadczenia życia spowodowały, że w pamfletach potępił zakony żebrzące (J. Świnka, Camus, w: Encyklopedia katolicka, t. II, red. F. Gryglewicz i [in.], Lublin: TN KUL, 1989, kol. 1308).

${ }^{40}$ Z. Wit, Fénelon de Salignac de la Mothe, w: Encyklopedia katolicka, t. V, red. L. Bieńkowski i [in.], Lublin: TN KUL, 1989, kol. 116-117.

${ }^{41}$ Concilium Romanum in Sacrosancta Basilica Lateranensi, s. 89-90; dostęp: https://play.google.com/books/reader?id=epReQxOChaAC\&printsec=frontcover \&output=reader\&hl=pl\&pg=GBS.PP5 (21.01.2018).

${ }^{42} \mathrm{~J}$. Heuclin, L'érémitisme au diocèse de Cambrai d'après l'institut des ermites de Fénelon (1714), w: Fénelon, évêque et pasteur en son temps, 1695-1715. Actes du colloque, Cambrai, 15-16 septembre 1995, red. A. Martine i [in.], Villeneuve-d'Ascq: Université Charles de Gaulle Lille III, Centre d'Histoire de la Région du Nord et de l'Europe du Nord-Oues, 1996, s. 109-124.
} 
di Annecy”, a następnie zwolniony z kościelnych urzędów udał się w 1635 r. w celach religijnych na roczny pobyt do pustelni „de Notre-Dame des Voirons" ${ }^{\prime 3}$. Następnie de Sales, kiedy został biskupem, złagodził eremitom przepisy ich konstytucji i doprowadził afiliacji eremitów do paryskiej prowincji dominikanów. Kongregacja eremitów w 1620 r. została zatwierdzona przez de Salesa († 1622), biskupa Genewy, który nadał im surowe konstytucje ${ }^{44}$.

Próby uporządkowania przez rezydencjalnych biskupów eremickiego życia zaowocowały m.in. wydaniem przez Antonio Daza, O.F.M., ćwiczeń duchownych Essercitii spirituali delli romitorii instituiti dal nostro Serafico Padre per utilità dei suoi frati, dedykowanego osobom udającym się w celach religijnych do miejsc o charakterze pustelniczym. Daza zalecał eremitom codzienne odprawianie po nieszporach drogi krzyżowej ${ }^{45}$. Opuszczone pustelnie w XVII w., zwłaszcza te we Flandrii i Bretanii, przekształcano w kapelanie zasiedlane przez duchowieństwo diecezjalne. Natomiast opuszczone pustelnie, zwłaszcza te położone w Lotaryngii i Burgundii, powierzano pod opiekę ubogim wieśniakom, często żyjącym w małżeństwach, którzy co prawda chętnie udawali się do eremów, ale nie po to aby uczestniczyć w eremickim życiu duchowym, lecz przede wszystkim w celu czerpania materialnych korzyści płynących ze zbierania jałmużny. Wieśniaków opiekujących się eremitarzami zaczęto nazywać „eremitami”, a ich żony „eremitkami”, co oczywiście nie sprzyjało budowaniu chlubnej opinii o moralności tzw. „eremitów”. Spowodowało to utrwalenie się w kulturze negatywnej opinii o moralności eremitów, co sprzyjało kolportowaniu krzywdzących stereotypów

\footnotetext{
${ }^{43}$ S. Coram-Meкney, Sales Charles-Auguste de, w: Dictionnaire historique de la Suisse, t. XI (De Sal à Stadtmann), Basel: Schwabe, Hauterive: G. Attinger, 2012, s. 825; dostęp: http://www.hls-dhs-dss.ch/textes/f/F26362.php (31.01.2018).

${ }^{44}$ Daniluk, Duchniewski, Eremici. IV. Wspólnoty, kol. 1081.

${ }^{45}$ Pop. A. DAzA, Essercitii spirituali delli romitorii. Instituiti dal nostro serafico p. S. Francesco per vtilità dei suoi frati. Dichiarati, e dedicati all'istesso santo dal p. fr. Antonio Daza dell'Ordine dei minori osseruanti [...]. Tradotti dalla lingua spagnuola nell'italiana dal padre fr. Luigi di Roma, theologo, e predicatore dell'istess'Ordine, In Roma: Per l'erede di Bartolomeo Zannetti, 1626.
} 
na temat moralności eremitów w literaturze religijnej, począwszy od XVI w. aż do XVIII w., które m.in. legły u podstaw wezwań do przeprowadzenia reformy eremickiego życia ${ }^{46}$.

W XVIII w. znanym eremitą wędrownym był Benedykt Labre $(† 1783)$, około połowy XIX w. Joseph-Marie Chiron († 1852), żyjący w okolicach Roussillon (k. Lyonu), a na przełomie XIX i XX w. Charles Eugène de Foucauld na Saharze $(† 1916)^{47}$.

\section{Poglądy kanonistów}

Roberto Francesco Bellarmino († 1621) w drugim tomie „De controversiis”, w księdze drugiej „De Monachis et Religiosis ceteris”, w rozdziale trzecim „De varijs Ordinibus Religiosorum”, odwołując się do dorobku starożytnych pisarzy, zaprezentował systematykę zakonów ze względu na cel, który przyświecał ich fundatorom. Eremitów zaliczył do prowadzących kontemplacyjny tryb życia ${ }^{48}$. Eremitom poświęcił rozdział 39. „De Eremitis”, w którym zaprezentował źródła życia eremickiego ${ }^{49}$.

Problematyka eremityckiego życia w okresie potrydenckim w doktrynie prawa kanonicznego rozpatrywana była m.in. przy okazji prowadzenia wykładu na temat „privilegium fori et canonis”, który zapewniał wyłączenie spod świeckiej władzy ${ }^{50}$.

Lucius Ferraris wyróżniał cztery grypy eremitów. Pierwsza obejmowała eremitów, którzy składali trzy śluby w jakimś zakonie uznanym przez władzę kościelną. Druga grupa obejmowała eremitów, żyjących w jakimś zgromadzeniu według zasad określonych przez rezydencjalnego biskupa i podlegających jego władzy. Eremici należeli

\footnotetext{
${ }^{46}$ DANILUK, Eremici, kol. 1077.

${ }^{47}$ Tamże.

${ }^{48}$ R.F. Bellarmino, Dispvtationvm Roberti Bellarmini Politiani Societatis Iesv. De Controversiis Christianae Fidei. Adversvs Hvius Temporis Haereticos, t. II, Venetiis: apud Ioan. Bapt. Ciottum Senensem, 1599, kol. 312-313.

${ }^{49}$ Tamże, kol. 434-440.

${ }^{50}$ L. Ferraris, Prompta bibliotheca canonica, juridico-moralis, theologica partim ascetica, polemica, rubricistica, historica, t. II, Lutetiae Parisiorum: J.-P. Migne, 1852, hasło: Clericus, kol. 594.
} 
do kongregacji eremickich, które nie były wprawdzie uznawane za zakony, ale cieszyły się podmiotowością prawną w Kościele katolickim. Trzecia grupa obejmowała eremitów, podlegający władzy rezydencjalnych biskupów, którzy nie prowadzili życia wspólnotowego, ale posługiwali w oratoriach lub kościołach podlegających władzy rezydencjalnych biskupów. Eremici ci nie składali profesji zakonnej, ale wielu $\mathrm{z}$ nich przestrzegało „continentiam perpetuam”. Czwarta grupa obejmowała tych eremitów, którzy co prawda mogli nosić habit, ale jednak traktowano ich jedynie jako „laików”. Eremici ci nie posługiwali w żadnym oratorium lub kościele i według swej woli swobodnie mogli porzucać eremicki habit. Lucius Ferraris jedynie czwartej grupie eremitów odmawiał prawa korzystania z „privilegium fori et canonis”. Elrenreich Pirhing uważał, że eremici należący do czwartej grupy mogli korzystać z „privlegium fori et canonis”, jeśli tylko byli przełożonymi szpitali erygowanych przez kompetentną władzę kościelną. Podobnie uważał odnośnie tych eremitów, którzy przebywali w takich szpitalach ${ }^{51}$. Podobnego zdania był również pap. Benedykt XIV ( $† 1758)$, który w „De synodo dioecesana libri tredecim in duos tomos distributi” również podzielił eremitów na cztery grupy $^{52}$.

Papież Benedykt XIV o eremitach również pisał w „De servorum Dei beatificatione et beatorum canonizatione”. Do czwartej grupy eremitów zaliczał w swym dziele tych eremitów, którzy nie sprawowali opieki nad żadnym oratorium lub kościołem i nie podlegali bezpośrednio kompetentnej władzy kościelnej. Pap. Benedykt XIV powoływał się na autorytet Tomasza z Akwinu (†1274), który pisał, że eremickie życie, prowadzone poprawnie, należy wyżej cenić niż cenobityczne. Tomasz z Akwinu uważał również, że podjęcie eremickiego

\footnotetext{
${ }^{51}$ L. Ferraris, Prompta bibliotheca, canonica, juridico-moralis, theologica partim ascetica, polemica, rubricistica, historica, t. III, Lutetiae Parisiorum: J.P. Migne, 1852, hasło: Eremita, kol. 724-725; pop. E. PIrHING, Jus canonicum. Nova methodo explicatum omnibus capitulis titulorum, t. II, Dilingae: formis academicis per Joannem Federle, 1722, s. 64.

${ }^{52}$ Benedicti Papae XIV, De synodo dioecesana libri tredecim in duos tomos distributi, lib. V, cap. III, nr 6, Ferrariae: Manfrè, 1756, s. 236-237, nr 6.
} 
stylu życia bez właściwego przygotowania jest niebezpieczne dla nowego adepta eremityzmu, chyba że łaska Boża uzupełniłaby braki w wymiarze antropologiczno-teologicznym, lub sam eremita, tak jak Antoni († 356) czy Benedykt z Nursji (†547), uzupełniliby braki poprzez ascezę $e^{53}$. Pap. Benedykt XIV uważał, że w przypadku prowadzenia procesu kanonizacyjnego jakiegoś eremity zaliczanego do trzeciej lub czwartej grypy, należałoby poszukiwać odpowiedzi na następujące pytania: jaka przyczyna legła u podstaw wyboru przez niego pustelniczego trybu życia?, w jakim miejscu przebywał?, kogo miał za "rector conscientiae”? jak wyglądało jego życie sakramentalne? i jakie praktykował środki pokuty? ${ }^{54}$.

\section{Podsumowanie}

Przemiany teologiczne oraz społeczno-polityczne spowodowały, że niezależny eremityzm indywidualny, prężny jeszcze w XVII w., stracił na sile w XVIII w., dla którego kresem świetności stały się czasy rewolucji francuskiej. Rezydencjalni biskupi, mając na celu podniesienie niskiego poziomu życia duchowego eremitów, dążyli przez swoją działalność legislacyjną do reformy niezależnego i indywidualnego życia pustelniczego. Opierając się na prawodawstwie papieskim, postanowieniach Soboru Trydenckiego i lokalnych synodów, podejmowali próby zagwarantowania indywidualnym i niezależnym eremitom właściwej organizacji, przy zachowaniu pustelniczego trybu ich życia na poziomie diecezjalnym. Formy organizacyjne

\footnotetext{
${ }^{53}$ „Vita solitariorum, si debite assumatur, praeeminet vitae sociali. Si autem absque praecedenti exercitio talis vita assumatur, est periculosissima, nisi per divinam gratiam suppleatur quod in aliis per exercitium acquiritur, sicut patet de beatis Antonio et Benedicto" (Sancti Thomae Aquinatis, Opera omnia iussu impensaque Leonis XIII P. M. edita, t. X, Secunda secundae Summae theologiae, q. 188 a. 8 co., Romae: Ex Typographia Polyglotta S. C. de Propaganda Fide, 1899, s. 535; w języku polskim: Tomasz z Akwinu, Suma teologiczna, t. XXIII, Charyzmaty. Szczególne dary i powołania $w$ Kościele [2-2. 171-189], red. P. Bełch, London: Veritas, 1982, s. 221).

${ }^{54}$ P.L. Lambertini (Benedictus PP. XIV), De servorum Dei beatificatione et beatorum canonizatione, t. III, cap. 35, nr 15, Bononiae: Longhi, 1737, s. 518-519.
} 
obejmowały powoływanie zgromadzeń eremitów z przełożonym generalnym na czele, który zazwyczaj eremitą bez święceń prezbiteratu, wspólnym nowicjatem, wizytatorami i doroczną kapitułą, sprawującą najwyższą władzę w zgromadzeniu. Kanoniści nie poświęcali zbytniej uwagi zagadnieniom związanym $\mathrm{z}$ indywidualnym i niezależnym eremityzmem, ponieważ nie uważali go za formę życia zakonnego. Swoje zainteresowania zogniskowane wokół eremitów podejmowali w kontekście dyskusji nad „privilegium fori et canonis”.

\section{The forms of canonical dependence of an individual hermit from the church hierarchy in the post-Tridentine sources of the law of the Latin Church}

The object of the article was to present forms of the canonical dependence of an individual and independent hermit from the Church hierarchy in the post-Tridentine sources of the Latin Church. The historical and legal method is used in this scientific article. Theological and social-political transformations during the post-Tridentine period in Europe contributed to the fact, that independent and individual eremitic life, flourishing in Catholic countries still in the 17th century, lost so much in its intensity in the 18th century that the French Revolution contributed to its extinction. Resident bishops, erecting or approving the non-order hermits' congregations, attempted to reform the independent and individual eremitic life. The canonists taking into account, among others things, the non-order nature of individual and independent eremitism, were not very interested in it. The author came to the conclusion that the legislation of the resident bishops attempted to make individual and independent eremitic or anchoritic life canonically similar to religious life.

SŁOWA KLUCZOWE: anachoreta; zgromadzenie niezakonne; konstytucje; kwesta; "privilegium fori”

KEYWORDS: anachoretta; non-order congregation; constitutions; alms; „privilegium fori" 


\section{Nota o Autorze:}

Ks. DR MARCIN BIDer - adiunkt w Instytucie Nauk o Polityce i Administracji na Wydziale Nauk Społecznych Uniwersytetu Przyrodniczo-Humanistycznego w Siedlcach. 